\title{
PERFORMANCE OF CHILD WITH CENTRAL AUDITORY PROCESSING DISORDERS (CAPD) IN SCHOOL - ACOUSTIC SCHOOL CONDITIONS, POTENTIAL DIAGNOSTIC CAPD
}

\author{
[FUNKCJONOWANIE DZIECKA Z CENTRALNYM \\ ZABURZENIEM PRZETWARZANIA SLUCHOWEGO (CAPD) - \\ WARUNKI AKUSTYCZNE SZKOLY, MOŻLIWOŚCI \\ DIAGNOSTYCZNE CAPD]
}

\author{
Irena Polewczyk
}

DOI: 10.18355/PG.2015.4.2.197-209

\begin{abstract}
This paper presents a theoretical approach to the Central Auditory Processing Disorders (CAPD). It shows symptoms, that it causes and the diagnoses of children with CAPD and shows also acoustic school condition which impact performance of children in a classroom.
\end{abstract}

\section{Keywords}

CAPD - Central Auditory Processing Disorders, diagnosis, acoustic school conditions

\section{Streszczenie}

Artykuł przedstawia teoretyczne podejście do zagadnienia centralnych zaburzeń przetwarzania słuchowego. Omawia symptomy, przyczyny i sposoby diagnozy dzieci z CAPD, a także warunki akustyczne w szkole, które mają wpływ na funkcjonowanie dziecka w klasie.

\section{Slowa kluczowe}

CAPD - zaburzenia centralnego przetwarzania słuchowego, diagnoza, warunki akustyczne w szkole

\section{Wprowadzenie}

Coraz częściej w przedszkolu i szkole nauczyciele stykają się z różnymi, często nowymi problemami wśród swoich podopiecznych. Coraz więcej problemów potrafią zauważyć i określić, lecz wciąż pojawiają się nowe wyzwania zarówno dla nauczycieli jak i badaczy. Patrząc z punktu widzenia badacza można zauważyć, że zastanawiamy się i opisujemy wciąż nowe zaburzenia, choroby, zjawiska, które jeszcze 20 lat wcześniej nie były znane. Zadajemy sobie pytanie czy to świat tak bardzo szybko się zmienia, czy ludzkie umiejętności diagnostyczno - dyskrypcyjne tak wzrosły, że potrafimy opisać coraz to nowsze zjawiska, wszędzie doszukując się czegoś nowego co odbiega od przyjętej społecznie normy. A może pojęcie normy ewaluuje i również jej granice zostały zatarte lub przeniesione w węższe rejony? Pomijając te wątpliwości, które de facto wymagają odrębnego rozwinięcia, możemy skupić się na nowo opisywanym zaburzeniu, które 
odnajdujemy w nielicznych publikacjach audiologicznych, foniatrycznych czy logopedycznych. Zaburzenie to CAPD (Central Auditory Processing Disorders) - Zaburzenie Centralnego Przetwarzania Słuchowego.

\section{Psychoakustyczne właściwości czlowieka prawidłowo słyszącego i prawidłowo funkcjonującego $\mathrm{w}$ warunkach halasu}

R. P. Woodworth, H. Schlosenberg w" Psychologii eksperymentalnej" rozpoczynają podrozdział swojej książki poświęcony słyszeniu człowieka w następujący sposób: „Współczesne „cuda” słuchowe - telefon, fonograf, radio - już nie wywołują takiego oszołomienia jak wtedy, gdy po raz pierwszy przedstawiono je publiczności;... Znacznie bardziej oszałamiający jest mały instrument, który stale był używany przez niezliczone pokolenia - struktura wielkości ziarnka grochu, ucho wewnętrzne, które może zbierać dźwięki z powietrza, analizować ich złożoność i pozwala nam rozróżniać subtelne różnice wysokości, donośności i barwy" (Woodworth, Schlosenberg, 1963: 464).

To małe ziarenko ma nieprzeciętne właściwości odbioru dźwięków z otoczenia. Częstotliwość dźwięków, które człowiek słyszący jest w stanie odbierać mieści się w przedziale od $16 \mathrm{~Hz}$ do $20000 \mathrm{~Hz}$. Jednak tak dobre parametry słyszenia nie są nam dane na całe życie. Co pół roku tracimy ok. $80 \mathrm{~Hz} \mathrm{z}$ dźwięków, które bardzo dobrze słyszymy, oznacza to, że w wieku 30 lat słyszymy już tylko ok. $15000 \mathrm{~Hz}$, a wieku 60 lat już niewiele ponad 8000 Hz. Najlepszą słyszalność mamy w wieku 3 lat (Szczepankowski, 1999).

Natężenie dźwięku, jest drugim ważnym parametrem słyszenia u człowieka. Wyraża ono wartość ciśnienia akustycznego przypadająca na jednostkę powierzchni i wyrażona jest $\mathrm{w}$ dB. Przykładowe natężenia dźwięków otaczających nas na co dzień podaje B. Szczepankowski, oto kilka przykładów:

- darcie papieru $(1 \mathrm{~m}) 35-40 \mathrm{~dB}$

- spokojna rozmowa $45-50 \mathrm{~dB}$ :

- głośna rozmowa $60-65 \mathrm{~dB}$

- $\quad$ silnik samochodu osobowego (6m) 70-75 dB

- $\quad \operatorname{krzyk}(1 \mathrm{~m}) 80-85 \mathrm{~dB}$

- $\quad$ świder pneumatyczny $(2 \mathrm{~m})-90-95 \mathrm{~dB}$

- pociąg pospieszny $(3 \mathrm{~m}) 100-105 \mathrm{~dB}$

- dyskoteka 110-115 dB

- granica bólu dla człowieka 125-130 dB

- $\quad$ silnik odrzutowy przy starcie $(10 \mathrm{~m}) 145-150 \mathrm{~dB}$

- hałas powodujący trwałe uszkodzenie słuchu $150-155 \mathrm{~dB}$

- hałas powodujący wstrząs mózgu 155-160 dB

- hałas śmiertelny powyżej $160 \mathrm{~dB}$ (Szczepankowski, 1999, p. 56).

Nasz słuch odpowiedzialny jest za następujące czynności: detekcję dźwięku, (wykrywanie), dyskryminację (rozróżnianie), lokalizację źródła dźwięku, rozróżnianie dźwięków mowy, analizę i syntezę, pamięć słuchową. 


\section{Zaburzenie Centralnego Przetwarzania Sluchowego - CAPD}

W literaturze foniatrycznej, audiologicznej, czy logopedycznej to nowe zaburzenie badacze próbują opisać i zdefiniować. W literaturze logopedycznej odnajdujemy definicję Z. Kurkowskiego, który CAPD definiuje następująco: - to - „Zauważalne zaburzenia w jednej lub więcej grupach mechanizmów i procesów związanych $\mathrm{z}$ różnorodnymi zachowaniami słuchowymi, takimi jak: lokalizacja i lateralizacja dźwięku, dyskryminacja słuchowa, rozpoznanie cech dźwięków, percepcja aspektów czasowych sygnału (rozdzielność czasowa, maskowanie, integracja i porządkowanie w czasie), zdolność odbioru sygnału przy występowaniu konkurencyjnych sygnałów akustycznych, zdolność do odbioru sygnałów o obniżonej redundancji (zniekształconych) (Kurkowski, 2013: 35-36).

To zespół objawów, które wynikają $\mathrm{z}$ deficytów opracowania informacji akustycznej w ośrodkowej części układu słuchowego pomimo prawidłowej czułości słuchu. Jedną z pierwszych definicji w literaturze audiologicznej jest definicja J. Katz`a, który CAPD określił jako: „niemożność pełnego wykorzystania słyszanego sygnału akustycznego przy prawidłowym jego odbiorze w strukturach obwodowych" (Kurkowski, 2013: 35).

Centralne zaburzenia przetwarzania słuchowego nie są klasyczną jednostką chorobową, ale powinny być traktowane jako zespół objawów, które mogą występować $\mathrm{w}$ wielu różnych populacjach klinicznych i mieć różnorodną etiologię. Klinicyści obserwowali już od wielu lat osoby, u których audiometryczne progi słyszenia są prawidłowe, lecz które mają problem ze słyszeniem i rozumieniem mowy $w$ środowiskach akustycznie niekorzystnych, np. z pogłosem lub dodatkowym szumem. Trudności te najczęściej dotyczyły zdolności fonologicznych, objętości i sekwencji czasowej, rozumienia mowy. Oprócz osób prawidłowo słyszących i zdrowych, obserwowano je również u osób z chorobami przewlekłymi, napadami padaczkowymi, uszkodzeniami ośrodkowego układu nerwowego. W literaturze przedmiotu odnajdujemy różne definicje zaburzenia procesów przetwarzania słuchowego. „Zaburzenia procesów przetwarzania słuchowego (Auditory Processing Disorders - APD) zdefiniowano jako niedobór występujący $\mathrm{w}$ procesach przetwarzania informacji na drodze słuchowej". (Keith, 2005: 367)

Eksperci ASHA (Brytyjskiego Towarzystwa Audiologicznego) definiują ośrodkowe zaburzenia przetwarzania słuchowego (CAPD) jako: „chorobę słuchu wynikającą z nieprawidłowej czynności mózgu, charakteryzującej się nieprawidłowym rozróżnianiem, separacją, grupowaniem, lokalizacją i porządkowaniem bodźców" (Keith, 2005: 367).

Jest to zespół objawów, które wynikają z deficytów opracowania informacji akustycznej w ośrodkowej części układu słuchowego pomimo prawidłowej czułości słuchu. Centralne zaburzenia przetwarzania słuchowego to niemożność pełnego wykorzystania słyszanego sygnału akustycznego przy prawidłowym jego odbiorze w strukturach obwodowych. Pomimo iż wielu autorów definiuje to jako chorobę, CAPD nie doczekało się zapisu zarówno w DSM - IV (klasyfikacja zaburzeń psychicznych Amerykańskiego Towarzystwa Psychiatrycznego (ang. Diadnostic and Statistical Manual of 
Mental Disorders), jak i ICD - 10 - Międzynarodowa Statystyczna Klasyfikacja Chorób i Problemów Zdrowotnych (International Statistical Classification of Diseases and Related Health Problems).

Można zatem podsumować, że osoba z CAPD to człowiek dobrze słyszący (dobre wyniki badań w testach słuchowych), ale niesłuchający.

\section{Objawy kliniczne CAPD}

Wśród objawów klinicznych centralnych zaburzeń przetwarzania słuchowego Robert Keith wymienia niezdolność do:

- rozumienia mowy, nawet przy normalnym progu słuchu,

- rozumienia mowy w słabszych warunkach akustycznych (np. w hałaśliwym otoczeniu),

- rozumienia mowy zniekształconej, lub niewyraźnej,

- uczenia się w oparciu o bodźce słuchowe (Keith, 2005: 367).

Charakterystykę dzieci z CAPD przeprowadziła również Joanna Mąka. Wskazała, że większość z tych dzieci to chłopcy, którzy wykazują prawidłowe progi słuchu $\mathrm{w}$ badaniu audiometrycznym (audiometria tonalna), lecz ich odpowiedzi na bodźce słuchowe są niestałe. Badania, które przeprowadziłam w zakresie percepcji słuchowej w latach 2011-2012 na populacji 278 dzieci, nie wskazały na zależność między poziomem umiejętności w zakresie percepcji słuchowej a płcią. Potwierdziły to równocześnie wnioski z badań Małgorzaty Lipowskiej, która sformułowała podobny wniosek. Badania nie były skupione na badaniach wokół CAPD, lecz wyłącznie na percepcji słuchowej i wyselekcjonowanych zadaniach wokół tej umiejetnosci (Polewczyk, 2013).

U dzieci z CAPD obserwuje się raz odpowiedź prawidłową na polecenia słowne, a raz nieadekwatną lub brak reakcji. Cechą charakterystyczną jest krótki czas utrzymania uwagi i łatwa męczliwość w przypadku zadań wymagających długotrwałej aktywności związanej ze słuchaniem. Bodźce słuchowe szybko rozpraszają dzieci, reagują one bowiem na wszystkie zasłyszane dźwięki, bez umiejętności separowania ich i kategoryzowania zgodnie z hierarchią ważności. Dzieci te często wykazują trudności w lokalizacji dźwięku, określenia odległości od źródła, rozróżniania cech prozodycznych i głośności dźwięków. W sytuacji słyszenia dźwięków głośnych często obserwujmy u nich zatykanie uszu, co wskazuje na wrażliwość na dźwięki głośne. Nauczyciele mogą zaobserwować trudności $\mathrm{w}$ rozumieniu długich i złożonych poleceń, instrukcji słownych, szczególnie w klasie szkolnej, w której towarzyszy wiele dźwięków dodatkowych, takich jak szuranie krzesłami, szum rozmów czy hałas na korytarzu. Dzieci często proszą o powtórzenie informacji, i to wielokrotnie. Mają również trudności w sekwencyjnym zapamiętaniu ciągów słów: dotyczących dni tygodnia, miesięcy, kolejności liczb, alfabetu. Wolniej reagują na informacje słuchowe, gdyż potrzebują czasu na przetworzenie usłyszanej informacji. (Mąka, 2011)

R. Keith zwraca również uwagę na objawy towarzyszące, występujące u dzieci z CAPD. Są to:

- problemy z czytaniem - słabiej opanowana umiejętność głoskowania i literowania, 
- zaburzona intonacja (mowa monotonna, cicha albo - odwrotnie bardzo szybka i zbyt głośna),

- zaburzona artykulacja i umiejętności językowe,

- frustracje wynikające $\mathrm{z}$ deficytów odbiorczych, nieśmiałość lub izolacja w klasie,

- nadwrażliwość na dźwięki,

- zmęczenie po przebywaniu w głośnym środowisku,

- częste bóle głowy,

- częste zastanawianie się nad tym, jak się pisze dany wyraz popełnianie błędów ortograficznych,

- $\quad$ przeskakiwanie w czytanym tekście z linijki do innej linijki oddalonej

o dwa, trzy wersy i powracanie znowu do początku,

- trudności w nauce języków obcych,

- nadmierna potrzeba hałasowania (Keith, 2005: 367).

Z. Kurkowski podaje za A.Tomatisem, że głównym objawem wyróżniającym centralne przetwarzanie słuchowe jest zaburzenia słuchania - wsłuchiwania się.

Słuchanie to w odróżnieniu od słyszenia zdolność człowieka polegająca na mobilizowaniu się, aby słyszeć. W czasie wsłuchiwania się człowiek jest obecny, zainteresowany, aktywny, wyprostowany, ma ożywiony wyraz twarzy. Słyszenie natomiast - formułując rzecz skrajnie - jest przeciwieństwem wsłuchiwania się. Słyszenie zależy od stanu narządu słuchu, podczas gdy we wsłuchiwaniu się człowiek w sposób świadomy percypuje dźwięki, które do niego docierają. (Kurkowski , 2013).

$\mathrm{W}$ dyskusjach naukowych często podnosi się głos w sprawie występowania zaburzeń centralnego przetwarzania słuchowego w innych zaburzeniach, a mianowicie w ADHD i autyzmie. Na razie jednak brak jest doniesień z badań nad tymi zagadnieniami.

\section{Diagnostyka CAPD}

Diagnostyka CAPD w Polsce jest na etapie prac przygotowawczych zmierzających do standaryzacji. Ustala się zatem baterie testów, które będą wyznacznikiem standardów postępowania. W kilku ośrodkach - głównie prywatnych przeprowadza się tego typu badania, już wybranymi testami, lecz badania te są bardzo drogie. Potrzeba jeszcze czasu, aby tego typu badanie stało się dostępne dla wszystkich, bo wówczas będzie można wyznaczyć skalę tego zjawiska w Polsce. Próby diagnozowania tego zaburzenia podjęto $\mathrm{w}$ wielu krajach anglojęzycznych i hiszpańskojęzycznych. Ponieważ ocena umiejętności słuchowych wymaga szerokiej wiedzy interdyscyplinarnej, diagnostyka CAPD zakłada również szeroki wachlarz badanych umiejętności. Na początku wyklucza się istnienie chorób lub innych zaburzeń, takich jak niedosłuch, choroby psychiczne, obniżone umiejętności intelektualne itp.

W Stanach Zjednoczonych częstotliwość występowania zaburzeń w ośrodkowych procesach przetwarzania słuchowego wśród dzieci szacowana jest na około 2-3\%; badania osób dorosłych w Wielkiej Brytanii wskazują, że zjawisko to dotyczy $10-20 \%$ badanych. Wciąż jednak brak doniesień 
polskich, co wynika z braku odpowiednich testów opracowanych dla języka polskiego.

Audiolodzy, foniatrzy zalecają interdyscyplinarna diagnostykę, która powinna obejmować:

- konsultacje $\mathrm{z}$ lekarzem audiologiem (BERA, audiometria, impedancja...),

- $\quad$ konsultacje psychologiczne (pomiar inteligencji testami werbalnymi i niewerbalnymi),

- konsultacje logopedyczne (ocena mowy biernej i czynnej oraz badanie słuchu fonemowego).

Dla języka polskiego podjęto próby standaryzacji niektórych testów zapożyczonych z języka angielskiego. Prezentuje je tabela 1.

\section{Tabela 1 Zestawienie testów i zadań do diagnostyki CAPD}

\begin{tabular}{|c|c|c|c|c|}
\hline $\begin{array}{l}\text { Nazwa } \\
\text { testu }\end{array}$ & Opis zadania & $\begin{array}{l}\begin{array}{l}\text { Procesy } \\
\text { sluchowe }\end{array} \\
\end{array}$ & $\begin{array}{l}\text { Procesy } \\
\text { behawioralne }\end{array}$ & $\begin{array}{l}\text { Kategoria } \\
\text { testu }\end{array}$ \\
\hline $\begin{array}{l}\text { Mowa w } \\
\text { szumie }\end{array}$ & $\begin{array}{l}\text { rozpoznanie } \\
\text { monosylab } \\
\text { W obecności hałasu } \\
\text { białego }\end{array}$ & $\begin{array}{l}\text { zamknięcie } \\
\text { słuchowe, } \\
\text { rozdzielenie } \\
\text { dwóch sygnałów } \\
\text { akustycznych, } \\
\text { dekodowanie } \\
\text { fonetyczne }\end{array}$ & $\begin{array}{l}\text { odbieranie bodźców } \\
\text { zmniejsza się przy } \\
\text { jednoczesnej } \\
\text { obecności sygnału } \\
\text { współzawodnicząceg } \\
\text { o }\end{array}$ & $\begin{array}{l}\text { test } \\
\text { jednoustny, } \\
\text { mowa } \\
\text { o obniżonej } \\
\text { redundancji }\end{array}$ \\
\hline $\begin{array}{l}\text { Mowa } \\
\text { filtrowana }\end{array}$ & $\begin{array}{l}\text { rozpoznawanie } \\
\text { monosylab przy } \\
\text { zastosowaniu filtra } \\
\text { niskoczęstotliwościo } \\
\text { wego }\end{array}$ & $\begin{array}{l}\text { zamknięcie } \\
\text { słuchowe, } \\
\text { dekodowanie } \\
\text { fonetyczne }\end{array}$ & $\begin{array}{l}\text { odbieranie bodźców } \\
\text { zmniejsza się przy } \\
\text { zniekształceniu } \\
\text { sygnału } \\
\text { akustycznego }\end{array}$ & $\begin{array}{l}\text { tekst } \\
\text { jednoustny, } \\
\text { mowa } \\
\text { o obniżonej } \\
\text { redundancji }\end{array}$ \\
\hline $\begin{array}{l}\text { Tekst } \\
\text { lączenia } \\
\text { obuusznego }\end{array}$ & $\begin{array}{l}\text { rozpoznawanie } \\
\text { monosylab, których } \\
\text { zakres niskich } \\
\text { częstotliwości jest } \\
\text { podawany do jednego } \\
\text { ucha, a wysokich } \\
\text { częstotliwości - } \\
\text { jednocześnie do } \\
\text { drugiego ucha }\end{array}$ & $\begin{array}{l}\text { interakcje } \\
\text { obuuszne }\end{array}$ & interakcje obuuszne & $\begin{array}{l}\text { interakcje } \\
\text { obuuszne }\end{array}$ \\
\hline $\begin{array}{l}\text { Masking } \\
\text { level } \\
\text { difference }\end{array}$ & $\begin{array}{l}\text { lateralizacja tonów } \\
500 \mathrm{~Hz} \text { w szumie, } \\
\text { rozpoznawanie tonów } \\
500 \mathrm{~Hz} \text { (w szumie) z } \\
\text { przesunięciem lub } \\
\text { bez przesunięcia w } \\
\text { fazie między uszami }\end{array}$ & $\begin{array}{l}\text { interakcje } \\
\text { obuuszne }\end{array}$ & interakcje obuuszne & $\begin{array}{l}\text { interakcje } \\
\text { obuuszne }\end{array}$ \\
\hline $\begin{array}{l}\text { Dichotic } \\
\text { digits }\end{array}$ & $\begin{array}{l}\text { przetwarzanie dwóch } \\
\text { par cyfr podawanych } \\
\text { obuusznie } \\
\text { (dichotycznie), } \\
\text { powtarzanie cyfr } \\
\text { słyszanych w jednym } \\
\text { uchu }\end{array}$ & $\begin{array}{l}\text { przewodzenie } \\
\text { sygnału między } \\
\text { półkulami, } \\
\text { integracja } \\
\text { obuuszna - } \\
\text { podzielność } \\
\text { uwagi, } \\
\text { separacja } \\
\text { obuuszna - } \\
\text { selektywność } \\
\text { uwagi }\end{array}$ & mowa dychotyczna & $\begin{array}{l}\text { mowa } \\
\text { dychotyczna }\end{array}$ \\
\hline
\end{tabular}




\begin{tabular}{|c|c|c|c|c|}
\hline $\begin{array}{l}\text { Słowa } \\
\text { spondejowe } \\
\text { podawane } \\
\text { jednocześni } \\
\text { e do obu } \\
\text { uszu }\end{array}$ & $\begin{array}{l}\text { powtarzanie czterech } \\
\text { słów podawanych do } \\
\text { obu uszu } \\
\text { jednocześnie }\end{array}$ & $\begin{array}{l}\text { przewodzenie } \\
\text { sygnału między } \\
\text { półkulami, } \\
\text { integracja } \\
\text { obuuszna - } \\
\text { podzielność } \\
\text { uwagi }\end{array}$ & mowa dychotyczna & $\begin{array}{l}\text { mowa } \\
\text { dychotyczna }\end{array}$ \\
\hline $\begin{array}{l}\text { Sekwencja } \\
\text { tonów o } \\
\text { różnej } \\
\text { wysokości }\end{array}$ & $\begin{array}{l}\text { rozróżnianie } \\
\text { i porządkowanie } \\
\text { tonów o różnej } \\
\text { wysokości }\end{array}$ & $\begin{array}{l}\text { procesy czasowe, } \\
\text { rozróżnianie } \\
\text { częstotliwości, } \\
\text { porządkowanie } \\
\text { w czasie, } \\
\text { znakowanie } \\
\text { lingwistyczne }\end{array}$ & $\begin{array}{l}\text { dyskryminacja } \\
\text { słuchowa, } \\
\text { rozpoznawanie cech } \\
\text { dźwięku, } \\
\text { czasowe aspekty } \\
\text { słyszenia } \\
\text { z włączeniem } \\
\text { rozdzielczości, } \\
\text { maskowania, } \\
\text { integracji } \\
\text { i porządkowania }\end{array}$ & $\begin{array}{l}\text { słuchowe } \\
\text { procesy } \\
\text { czasowe } \\
\text { i rozróżniani } \\
\text { a dźwięku }\end{array}$ \\
\hline $\begin{array}{l}\text { Sekwencja } \\
\text { tonów o } \\
\text { różnej } \\
\text { długości }\end{array}$ & $\begin{array}{l}\text { rozróżnianie i } \\
\text { porządkowanie } \\
\text { tonów o różnym } \\
\text { czasie trwania }\end{array}$ & $\begin{array}{l}\text { konfiguracje } \\
\text { czasowe, } \\
\text { rozróżnianie } \\
\text { czasu trwania } \\
\text { bodźca, } \\
\text { porządkowanie } \\
\text { w czasie, } \\
\text { znakowanie } \\
\text { lingwistyczne }\end{array}$ & $\begin{array}{l}\text { dyskryminacja } \\
\text { słuchowa, } \\
\text { rozpoznawanie cech } \\
\text { dźwięku, } \\
\text { zzasowe aspekty } \\
\text { słyszenia } \\
\text { z włączeniem } \\
\text { rozdzielczości, } \\
\text { maskowania, } \\
\text { integracji } \\
\text { i porządkowania }\end{array}$ & $\begin{array}{l}\text { słuchowe } \\
\text { procesy } \\
\text { czasowe } \\
\text { i rozróżniani } \\
\text { a dźwięku }\end{array}$ \\
\hline $\begin{array}{l}\text { Test } \\
\text { rozróżniani } \\
\text { a przerw }\end{array}$ & $\begin{array}{l}\text { wykrywanie przerw } \\
\text { między dwoma } \\
\text { bodźcami }\end{array}$ & $\begin{array}{l}\text { rozdzielczość } \\
\text { czasowa }\end{array}$ & $\begin{array}{l}\text { dyskryminacja } \\
\text { słuchowa, } \\
\text { rozpoznawanie cech } \\
\text { dźwięku, } \\
\text { zzasowe aspekty } \\
\text { słyszenia } \\
\text { z włączeniem } \\
\text { rozdzielczości, } \\
\text { maskowania, } \\
\text { integracji } \\
\text { i porządkowania }\end{array}$ & $\begin{array}{l}\text { słuchowe } \\
\text { procesy } \\
\text { czasowe i } \\
\text { rozróżniania } \\
\text { dźwięku }\end{array}$ \\
\hline
\end{tabular}

Źródło: A. Fuente, B. McPherson, Ośrodkowe procesy przetwarzania stuchowego: wprowadzenie $i$ opis testów możliwych do zastosowania u pacjentów polskojęzycznych, „Otolaryngologia 2007, nr 6(2), p. 72.

Zaprezentowane w tabeli testy nie są łatwe, wymagają dobrej współpracy z pacjentem, niektóre $\mathrm{z}$ nich są zarezerwowane dla dzieci od lat 10.

Ośrodek poznański podjął próbę opracowania testu dla dzieci młodszych (w wieku przedszkolnym); twórcą testu jest prof. Edward Ozimek. Test polega na wskazywaniu właściwego obrazka wśród czterech demonstrowanych, różniących się w niewielkim stopniu w opisie słownym lub też powtarzaniu zdań. Zarówno pierwsza wersja (dla dzieci młodszych) jak i druga wersja polega na tym, ze dziecko słyszy dane zdanie w narastającym szumie. Poszczególne zdania są słyszane przez dziecko w szumie na początku łagodnym, a stopniowo narastającym do momentu, aż dziecko popełni błąd. Wówczas poziom szumu podawany dziecku do ucha zmniejsza się i w kolejnych zdaniach znowu narasta. W latach 2013-2014 test prof. Ozimka, 
służący do diagnozy CAPD, został upowszechniony. Obecnie trwają badania w kierunku statystycznego opracowania testu zmierzającego do standaryzacji.

\section{Współczesne warunki akustyczne dziecka}

Hałas traktujemy jako dźwięki niepożądane, które nas drażnią i denerwują. Jest jednak sprawą indywidualną, czy dany dźwięk jest już na granicy hałasu, czy jest też akceptowany w pełni. Widoczne dysproporcje w postrzeganiu hałasu uwidaczniają się w standardowej sytuacji szkolnej, dzieciom na przerwie nie przeszkadza hałas, a nauczycielom hałas na korytarzu jest sporą przeszkodą. Różnice to wynikają zarówno z procesów fizjologicznych związanych z wiekiem i doświadczeniem słuchowym osób dorosłych, jak również pewnej kultury bycia danych osób.

Wszechogarniający nas hałas, który słyszymy jest już często niezauważalny, bo na drodze habituacji przyzwyczajamy się do pewnych dźwięków w otoczeniu. Współczesność zapewniła mam wiele komfortowych urządzeń ułatwiających nam życie, producenci prześcigają się, aby produkt ich był najlepszy, również najcichszy, lecz przybywa urządzeń, które oprócz pomocy $\mathrm{w}$ codziennym życiu nieustannie emitują szereg głośnych dźwięków. Urządzeń w domu, miejscu pracy i rekreacji przybywa, a wraz z nim dodatkowych źródeł hałasu. W naszych domach hałasują nieustannie komputery, lodówki, pralki, wentylatory, przed domami - samochody. Analizy map akustycznych w Polsce pokazują, że największym źródłem hałasu są pojazdy komunikacji miejskiej. Różnice w głośności widać bardzo wyraźnie między dniem a nocą, kiedy ruch uliczny jest dużo mniejszy. Wartości w ciągu dnia mieszczą się w granicach od $75 \mathrm{~dB}$ do 90 $\mathrm{dB}$ przy ruchliwych ulicach, natomiast $\mathrm{w}$ ciągu nocy wartości te spadają do około $50 \mathrm{~dB}$. (dane zaczerpnięte z map akustycznych miast Polski).

$\mathrm{Z}$ czasem ten wszechobecny hałas przynosi nieuchronnie skutki uboczne np.:

- obniżenie progu słyszenia,

- przewlekłe choroby narządu głosu spowodowane wysokim poziomem hałasu (guzki śpiewacze, wtórne zmiany przerostowe fałdów głosowych, niedowład mięśni przywodzących i napinających fałdy głosowe z niedomykalnością fonacyjną głośni i trwałą dysfonią),

- rozdrażnienie,

- agresję,

- zmęczenie,

- brak koncentracji,

- choroby somatyczne (Augustynska, Radosz, 2009/10 ).

Dźwięki o wartości 35 - $70 \mathrm{~dB}$ wpływają na zmęczenie układu nerwowego człowieka, poważnie utrudniają koncentrację uwagi, zrozumiałość mowy, zasypianie i wypoczynek

Dźwięki o wartości 85 - $130 \mathrm{~dB}$ powodują liczne schorzenia organizmu ludzkiego, uniemożliwiają zrozumiałość mowy nawet z odległości $0,5 \mathrm{~m}, \mathrm{w}$ 
sytuacjach nagłego głośnego dźwięku nawet mogą spowodować śmierć człowieka.

Niepokojącym zjawiskiem jest również coraz głośniej słuchana muzyka przez dzieci, która jest bezpośrednio puszczona do kanału słuchowego. Jako dorośli nie mamy już często wpływu na głośność takiej muzyki. Zbyt głośna muzyka koncentrowana bezpośrednio w kanał słuchowy daje w krótkim czasie skutki uboczne podobne do wyżej wymienionych.

Warunki akustyczne w Polsce wokół szkoły oraz w szkole są regulowane prawnie, Dziennik Ustaw z roku 2012 wyraźnie reguluje wartości dźwięku: „Dopuszczalny poziom hałasu w terenie zabudowanym, związanym ze stałym lub czasowym pobytem dzieci to 56-61 dB." (ale brak informacji o dopuszczalnych częstotliwości dźwięków) (Dz. U. 2012 r. poz. 1109).

Badania dotyczące rozkładu poziomu dźwięku wokół budynków szkolnych oraz wewnątrz szkół w Polsce prowadziła Danuta Augustyńska i Jan Radosz. Badania przeprowadzono w 1336 szkołach miast wojewódzkich. Rozkład równoważnego poziomu dźwięku wokól obiektów szkolnych przedstawia się następująco:

- ok. 25\% szkół poziom głośności ma na poziomie $60 \mathrm{~dB}$,

- ok. $20 \%-55 \mathrm{~dB}$,

- ok. $15 \%-65 \mathrm{~dB}$,

- ok.. $12 \% 70 \mathrm{~dB}$,

- reszta to wartości do $10 \mathrm{~dB}$ i powyżej $75 \mathrm{~dB}$. (Augustynska, Radosz, 2009/9).

Porównując te wyniki $\mathrm{z}$ badaniami przeprowadzonymi $\mathrm{w}$ Londynie (przebadano 142 szkoły londyńskie) wyniki wydają się zbliżone. Największa wartość procentowa dotyczy dźwięków o tych samych parametrach co w Polsce, wyrażona jest jednak wyższą wartością procentową:

- $\quad$ ok. $45 \%$ szkół ma poziom głośności na poziomie do $60 \mathrm{~dB}$,

- ok. $25 \%$ - do $65 \mathrm{~dB}$,

- ok.. $25 \%$ - do $55 \mathrm{~dB}$

- pozostałe wartości procentowe obejmują zarówno niższe jak i wyższe poziomy głośności (Augustyńska, Radosz, 2009/9).

Badania poziomu głośności w polskich szkołach na korytarzach szkół podstawowych i średnich podczas przerwy wskazują, że więcej, bo aż 50\% szkół średnich wykazuje poziom głośności na poziomie $80 \mathrm{~dB}$, natomiast najwięcej szkół podstawowych - 25\% - głośność ma na poziomie $85 \mathrm{~dB}$, a $20 \%$ na poziomie $90 \mathrm{~dB}$. Wynika z tego, że głośniejsze przerwy są w szkołach podstawowych.

Głośność w klasie może być spowodowana róznymi czynnikami: aktywnością uczniów i nauczyciela, jak również różnymi urządzeniami, czy też dźwiękami z sąsiednich sal i korytarza. Badania poziomu głosności podczas lekcji pokazują podobna tendencję - głosniej jest w szkołach podstawowych - ok. $20 \%$ lekcji w szkolach podstawowych odbywa się na poziomie głosnosci ok. $70 \mathrm{~dB}$, najwiekszą wartość procentowa w szkołach średnich odnajdujemy na poziomie gółosnosci $60 \mathrm{~dB}$ (to aż 50\% lekcji - 
jest to poziom głosnosci odpowiadajacy rozmowie potocznej). (Augustyńska, Radosz, 2009/9).

W londyńskich szkołach prowadzono analizy dotyczące porównania poziomu głośności przy różnych aktywnościach uczniów. Najgłośniejszą sytuacja dydaktyczna okazała się praca w grupach. Wartości poszczególnych czynności przedstawiają się następująco:

- $\quad$ Ciche czytanie - 56,3 dB

- 1 osoba mówiąca $-61,2 \mathrm{~dB}$

- Praca indywidualna (uczniowie siedzą)- 64,7 dB

- Praca indywidualna i poruszanie się po klasie - 72,2 dB

- Praca w grupach (uczniowie siedzą) - 72,9 dB

- Praca w grupach uczniowie i poruszanie się po klasie - 76,8 dB (Augustyńska, Radosz, 2009/9).

Kolejne badania i analizy uwzględniały różne pomieszczenia szkolne. Poniższe zestawienie prezentuje wybrane wyniki badań.

- Klasy z uczniami - 72,1 dB

- Klasy puste $-47,0 \mathrm{~dB}$

- Korytarze/schody $-58,1 \mathrm{~dB}$

- Hole z uczniami - 73,4 dB

- Hole puste - 53,2 dB (Augustyńska, Radosz, 2009/9).

$\mathrm{Z}$ podanych badań wynika, że podobną głośność badacze odnotowali zarówno w holach szkolnych jak i klasach $\mathrm{z}$ uczniami. Wartość tych parametrów (ok. $70 \mathrm{~dB}$ ) pokazuje, że miejsce, które powinno być optymalnym miejscem pracy ucznia jest akustycznie nieprzychylnym miejscem.

Przedstawione warunki akustyczne klasy i szkoły są trudnymi warunkami do uczenia dla dzieci z CAPD. Zbyt duża ilość dźwięków oraz ich głośność nie pozwalają bowiem dobrze odbierać komunikatów słownych kierowanych do nich od nauczyciela, czy innych dzieci. Hałas bowiem wpływa na maskowanie i zrozumiałość mowy.

Wiele krajów w ramach eliminowania hałasu i jego negatywnego wpływu na jakość edukacji wprowadziło szeregu norm i wytycznych, które głównie dotyczą wyznaczenia: granicznych wartości poziomu hałasu wewnątrz budynków, maksymalnych czasów pogłosu w klasach, wymaganej izolacji akustycznej ścian wewnętrznych i zewnętrznych szkoły. Wprowadzenie w klasach płyt dźwiękochłonnych spowodowało obniżenie poziomu hałasu od 5 do $12 \mathrm{~dB}$ oraz skróciło czas pogłosu od 0,75 s do 0,35 s. (Augustynska, Radosz, 2009/10).

\section{Propozycje wsparcia dzieci z CAPD}

Tak jak wiele zaburzeń, również CAPD wymaga odpowiedniego podejścia terapeutycznego.

Wśród zalecanych terapii dla dzieci z CAPD wymieniane są:

- terapia słuchowa wg Tomatisa - trening słuchowy. Celem tej metody jest wspieranie funkcji słuchowych przy użyciu muzyki Mozarta, chorałów gregoriańskich i głosu matki. Program obejmuje od 60 do 120 seansów przeprowadzonych w trzech sesjach. Jeden seans trwa 30 minut. Dzięki tej terapii następuje poprawa koncentracji i jakości 
uczenia się, rozwijanie zdolności językowych i komunikacyjnych, a także zwiększanie kreatywności oraz poprawa zachowań społecznych;

- indywidualna stymulacja słuchu K. Johansena IAS - to metoda polegająca również na słuchaniu filtrowanej muzyki instrumentalnej. Jedna sesja trwa 10 minut dziennie, cała terapia zaś od 6 do 10 miesięcy;

- Auricula TM - w tej metodzie występuje poszerzenie treningu słuchowego o stymulacje innych zmysłów, zwykle percepcję wzrokową. Dziecko, słuchając zmodyfikowanej muzyki, ma za zadanie synchronizować dźwięk z zadaniem w obrębie wzroku - odszukać właściwy kształt figury lub kolor;

- Fast for Word - to specjalnie skonstruowany program komputerowy, w którym zadaniem dziecka jest rozpoznawanie kolejności dźwięków, sekwencjonowanie dźwięków, przyporządkowanie dźwięku do właściwej litery itd.;

- polimodalna stymulacja percepcji sensorycznej Skarzyńskiego - to terapia poprzedzona szczegółową diagnozą i ustaleniem zakresu deficytu słuchowego oraz dopasowaniem ćwiczeń do tych braków; (Kurkowski, p. 41-49),

- program stymulacji percepcji słuchowej I. Polewczyk - zawierający zestawy ćwiczeń $\mathrm{z}$ poszczególnych zakresów percepcji słuchowej: ćwiczenia w obrębie słuchu fizycznego, odtwarzanie struktur dźwiękowych, wyróżnianie wyrazów w zdaniu (analiza zdaniowa), ćwiczenia pamięci słuchowej, rozpoznawanie rymów oraz umiejętność tworzenia rymów, rozpoznawanie aliteracji, analiza i synteza sylabowa słów i pseudosłów, analiza i synteza fonemowa słów i pseudosłów, analiza i synteza logatomowa, przekształcanie słów, połączenia głoska-litera, ćwiczenia w różnicowaniu głosek opozycyjnych, ćwiczenia słuchu prozodycznego, ćwiczenia pamięci sekwencyjnej; (Polewczyk, 2013),

- zastosowanie w klasie systemu FM - to urządzenie składające się z nadajnika i małej słuchawki umieszczonej na uchu dziecka, umożliwiające lepszą koncentrację na mowie nauczyciela - urządzenie wzmacnia dźwięk, który słyszy uczeń;

- modyfikacje środowiskowe - modyfikacje akustyki sali lekcyjnej (zbyt duży pogłos, szum w klasie) poprzez wygłuszenie dźwięków przez użycie dywanów, zasłon lub gąbek na ścianach; zlikwidowanie urządzeń, które emitują dźwięki, np. tykających zegarów itp.; zmiana miejsca dziecka w klasie, tak aby nauczyciel miał z nim stały kontakt i aby był możliwy kontakt wzrokowy; użycie pomocy multimedialnych; stała kontrola tego, czy dziecko rozumie polecenia i czy je wykonuje.

\section{Konkluzja}

Zaburzenia centralnego przetwarzania słuchowego wymagają jeszcze wielu poszukiwań badawczych w zakresie diagnostyki, częstotliwości występowania oraz coraz skuteczniejszych strategii postepowania terapeutycznego. Ważne jest aby również wiedza nauczycieli w tym 
zakresie również poszerzała się, aby nauczyciel szukał dróg wsparcia i pomocy dla takiego ucznia. Funkcjonowanie bowiem dziecka z CAPD w szkole jest trudnym wyzwaniem zarówno dla nauczyciela jak i rodzica. Opracowanie właściwych, rzetelnych narzędzi diagnostycznych pozwoli lepiej rozpoznać zjawisko, a poszukiwanie właściwych metod wsparcia jest stale podejmowane przez wielu badaczy. Współczesne środowisko akustyczne nie sprzyja uważnemu słuchaniu, ważne jest zatem, aby zadbać o dobre warunki akustyczne dla rozwoju naszych dzieci, wyeliminować niepotrzebne dźwięki, które utrudniają koncentrację słuchową.

\section{Bibliography}

AUGUSTYNSKA, D. - RADOSZ, J. 2009. Hałas w szkołach - przegląd badan. Bezpieczenstwo pracy - Nauka i polityka, vol. 9, p.16-19.

AUGUSTYNSKA, D. - RADOSZ, J. 2009. Hałas w szkołach (2) - wpływ hałasu szkolnego na uczniów i nauczycieli oraz jego profilaktykaBezpieczeństwo pracy, vol. 10, pp. 8-10. Available online: http://archiwum.ciop.pl/36063

FUENTE, A., MCPHERSON, B. 2007. Osrodkowe procesy przetwarzania słuchowego, wprowadzenie $\mathrm{i}$ opis testow mozliwych do zastosowania $\mathrm{u}$ pacjentow polskojęzycznych. In: Otolaryngologia vol. 6, n. 2, p. 66-76, ISSN 20833326.

KACZMAREK, B. 1998. Mozg, język, zachowanie: Lublin. ISBN 8322707258.

KEITH, R. 2005. Zaburzenia procesow przetwarzania słuchowego, [w:] Audiologia kliniczna, red. M. Sliwinska-Kowalska, Łodz. ISBN 8301343383

KURKOWSKI, Z. 2013. Audiogenne uwarunkowania zaburzen komunikacji jezykowej, Lublin. ISBN 9788377843963

MAKA, J. 2011. Zaleznosci pomiedzy zaburzeniami procesow przetwarzania słuchowego a specyficznymi zaburzeniami rozwoju jezykowego. Probki testow dla jezyka polskiego w ocenie CAPD i SLI, [w:] Biologiczne uwarunkowania rozwoju i zaburzen mowy, red. M. Michalik, Krakow. ISBN 9788376240855

POLEWCZYK, I., 2013. Diagnozowanie i stymulowanie rozwoju percepcji słuchowej dzieci w wieku przedszkolnym, Warszawa. ISBN 9788362015627

POLEWCZYK, I. 2014. Dziecko z CAPD (Centralnymi Zaburzeniami Przetwarzania Słuchowego) w szkole - strategie diagnostyczne i terapeutyczne. Krakow: Libron, ISBN 9788364275739.

ROZPORZADZENIE MINISTRA ŚRODOWISKA zmieniajace rozporzadzenie w sprawie dopuszczalnych poziomów hałasu w srodowisku, Dziennik Ustaw Rzeczpospolitej Polskiej, 8 pazdziernika 2012 roku, poz. 1109.

SZCZEPANKOWSKI, B.1999. Niesłyszący - głusi - głuchoniemi. Wyrownywanie szans, Warszawa. ISBN 8302073962

WOODWORTH, R. P. - SCHLOSENBERG, H. 1963. Psychologia eksperymentalna, t. 1, Warszawa. (ISBN brak) 
dr hab. Irena Polewczyk

University Śląski

Chair of Early Education and Pedagogy Media

Ul. Grażyńskiego 53, 40-126 Katowice

Poland

irena.polewczyk@up.edu.pl 